DOI: $10.2478 / \mathrm{v} 10014-012-0005-4$

COBISS Code 1.01

Agrovoc descriptors: ambrosia, water use, efficiency, nitrogen, proximate composition, water, plant physiology, water uptake, water metabolism, plant water relations, noxious plants, weeds

Agris category code: F62, F60, H60

\title{
Water and nitrogen use efficiency of common ragweed (Ambrosia artemisiifolia L.) at different nitrogen and water levels
}

\author{
Robert LESKOVŠEK ${ }^{\mathrm{a}}$, Klemen ELER ${ }^{\mathrm{b}}$, Franc BATIČ $^{\mathrm{b}}$, Andrej SIMONČIČ ${ }^{\mathrm{a}}$
}

Received February 01, 2012; accepted February 27, 2012.

Delo je prispelo 01. februarja 2012, sprejeto 27. februarja 2012.

\begin{abstract}
Common ragweed (Ambrosia artemisiifolia L.) spread across Europe and other regions is becoming a serious health and economic threat. A pot experiment was conducted in 2011 to determine effect of various nitrogen $(\mathrm{N})(10,100 \mathrm{~kg} / \mathrm{ha})$ and water supply regime on resource use efficiency of ragweed. Ragweed plants increased their dry matter production with increased water and $\mathrm{N}$ availability. Nitrogen use efficiency (NUE) was decreased with $\mathrm{N}$ addition and was not influenced by water availability. Mean nitrogen residence time (MRT) was longer at low $\mathrm{N}$ and water levels. In contrast, nitrogen productivity (NP), NUE and water use efficiency (WUE) were all increased with enhanced water supply. A trade-off between parameters of NUE was attributed to differential response of NP and MRT to soil fertility and water supply. Our results confirmed that ragweed displayed high adaptation to unproductive sites. However, ragweed's greater plasticity in response to water availability compared to $\mathrm{N}$ availability suggest, that water supply plays important role in its invasion success and in combination with disturbance ragweed might further spread into more productive environments.
\end{abstract}

Key words: Ambrosia artemisifolia, invasivity, water use efficiency, nitrogen use efficiency, pot experiment, Slovenia

\section{IZVLEČEK}

\section{UČINKOVITOST IZRABE VODE IN DUŠIKA PRI PELINOLISTNI AMBROZIJI (Ambrosia artemisiifolia L.) OB RAZLIČNIH RAVNEH DUŠIKA IN VODE}

Pelinolistna ambrozija (Ambrosia artemisiifolia L.) postaja s svojim nezadržnim širjenjem po Evropi in drugih regijah sveta resen ekonomski in zdravstveni problem. Za določitev učinkovitosti izrabe virov je bil v letu 2011 zasnovan lončni poskus z dvema obravnavanjema $\mathrm{z}$ dušikom (N) (10 in 100 $\mathrm{kg} / \mathrm{ha}$ ) in vodo (veliko, malo vode). Pelinolistna ambrozija je povečala produkcijo suhe mase pri večjih odmerkih dušika in vode. Učinkovitost izrabe dušika (NUE) se je pri večjem odmerku dušika statistično značilno zmanjšala, preskrba z vodo pa ni imela vpliv na NUE. Srednji čas zadrževanja dušika v rastlini (MRT) je bil daljši pri manjših odmerkih dušika in manj vode. Nasprotno so se produktivnost dušika (NP), NUE in učinkovitost izrabe vode (WUE) pri večji dostopnosti vode povečali. Kompromis med faktorji NUE je bil pripisan različnemu odzivu NP in MRT na preučevane dejavnike dušika in vode, pri čemer je bil odziv pelinolistne ambrozije pri različnih odmerkih vode bolj plastičen $v$ primerjavi $\mathrm{z}$ različnimi odmerki dušika. Naši rezultati so potrdili, da je pelinolistna ambrozija prilagojena na neproduktivna rastišča, vendar nakazujejo, da ima voda velik vpliv pri invazivnem uspehu pelinolistne ambrozije in bi se, glede na izkazano plastičnost, $\mathrm{v}$ motenih okoljih lahko razširila tudi $\mathrm{v}$ bolj produktivna rastišča.

Ključne besede: Ambrosia artemisifolia, invazivnost, učinkovitost izrabe vode, učinkovitost izrabe dušika, lončni poskus, Slovenija

\footnotetext{
a Agricultural Institute of Slovenia, Hacquetova ulica 17, 1000, Ljubljana, Slovenia

b University of Ljubljana, Biotechnical Faculty, Agronomy Department, Jamnikarjeva 101, 1000 Ljubljana, Slovenia
} 


\section{INTRODUCTION}

The ecology of plant resource use is one of the most important topics as plants differ considerably in their resource use and adaptive strategies to varying growing conditions. Determination of plants resource use efficiency is widely used approach to study significant adaptive traits. Resource use efficiency is defined as the ratio between output parameter (biomass production, seed production, photosynthetic carbon gain) and a resource input parameter (light absorption, nutrient uptake, water uptake). Successful invasive plants tend to have morphological and physiological traits that enable them to acquire resources in the limiting environments (Funk and Vitousek, 2007) or respond plastic with morphological and physiological adjustment to contrasting resource availabilities (Claridge and Franklin, 2002).

Common ragweed (Ambrosia artemisiifolia L.) (hereafter referred to as ragweed) is an annual monoecious weed (Asteraceae), introduced to Europe in the eighteenth century (Bonnot, 1967). Since then, it has spread over many European countries (Chauvel et al., 2006; Vogl et al., 2008). In Europe, as in North America, ragweed is considered a troublesome weed and a pioneer plant of abandoned and degraded areas, such as roadsides, fallow fields and other disturbed habitats, where the species takes advantage of the reduced competitiveness from native species or tolerates severe growing conditions (DiTommaso, 2004; Fumanal et al., 2008a). Lastly, ragweed represents a major human health problem because its pollen is a strong allergen that causes ocular and respiratory allergies that often develop into asthma (Dahl et al., 1999; Ziska, 2001). In North America, ragweed pollen is known as one of the main causes of hay fever (allergic rhinitis) (Mitich, 1996) or a form of dermatitis in some people.

Although alien plant invasion, as experienced in the case of ragweed, have become increasingly frequent, plant resource use efficiency and ecological traits underlying the invasion are still poorly understood. High resource use efficiency as well as enhanced phenotypic plasticity have been hypothesized as decisive plant traits allowing the species to become invasive in newly colonized habitats (Dukes and Mooney, 1999), comparing also ecophysiological traits of species growing in invaded and native stands (Durand and Goldstein, 2001). It has been documented that some invasive species posses significantly higher photosynthetic nitrogen use efficiency (PNUE), water use efficiency (WUE), and higher specific leaf area (SLA) than native species (Durand and Goldstein 2001; Niinemets et al. 2003; Feng et al., 2007). Performance of plant species in terms of dry matter production is limited by the availability of nutrients in many seminatural communities (Vitousek and Howarth, 1991). As nitrogen is one of the main limiting growth resources, the nitrogen use efficiency (NUE) of plant species has been widely subjected to studies. NUE is generally determined as productivity per unit $\mathrm{N}$ uptake or loss (Vitousek, 1982). NUE is a measure of how plant responds to soil nitrogen, defined as the amount of organic matter lost or produced in a plant per amount of nitrogen used. Berendse and Aerts (1987) further divided NUE to two components: nitrogen productivity (NP) and the mean residence time of nitrogen in the plant (MRT). NP is the rate of dry matter production per unit of $\mathrm{N}$ content in the plant and MRT is the period during which the absorbed nitrogen can be used for carbon fixation. Most studies on NUE have tried to discover patterns in the NUE of species in relation to nitrogen availability in their natural habitat. Soil water supply also affects nutrient transport, uptake, and transformation. Furthermore, it may be the underlying cause of variation in habitat fertility. Plants developing in environments with different soil water supply regimes can exhibit differences in traits such as photosynthetic capacity, growth rate, leaf $\mathrm{N}$ content (Lambers et al., 1998) which are correlated with NUE and could thus potentially affect $\mathrm{N}$ use strategy. Identifying plant traits associated with invasiveness is necessary for possible control of existing invasive species or potentially to predict new invasive species, their traits and target habitats before introduction. Most of the invasive species occur in highly disturbed resource rich environments (Daehler, 2003; Gross et al., 2005; Huenneke et al., 1990), but increasing evidence indicates that invasion is also a danger in resource-poor communities, though the mechanisms of low-resource invasion are less well understood (Mack et al., 2000; Funk and Vitousek, 2007 ). Altough ragweed is adapted to low nutrient environments, it is likely that in combination of better nutrient supply and disturbance, it can spreads into more productive habitats and it can be found on variety of plant communities, soil types and site productivities (Fumanal, 2008b). Despite increased research efforts in past decade have been undertaken, still little information is available on ragweed resource use efficiency.

Our study was therefore oriented on determing ragweed's resource use efficiency under different nitrogen and water levels. We hypothesized that ragweed plants would increase its dry mater production with addition of nitrogen and water. Conversely, with increased $\mathrm{N}$ and water supply its NUE and WUE will decrease. We were also interested in variations and plasticity of the species underlying NUE components of nitrogen economy (NP and MRT) in the response to resource supply. Finally, we studied the existence of the hypothesized trade-off between NP and MRT, components of NUE. 


\section{MATERIAL AND METHODS}

A pot experiment was conducted in the experimental field of Biotechnical Faculty, University of Ljubljana, over three months from July to September 2011. The experiment consisted of a randomised factorial design with four replications. The experimental units (pots) were randomly assigned to each combination of $\mathrm{N}$ availability (two levels), water availability (two levels) and sampling time (growth stage; three levels) with four replicates per combination. In total, 96 pots were used in the experiment. The total $\mathrm{N}$ addition levels were $0.08 \mathrm{~g} / \mathrm{pot}(10 \mathrm{~kg} / \mathrm{ha})$ and $0.8 \mathrm{~g} / \mathrm{pot}(100$ $\mathrm{kg} / \mathrm{ha}$ ) over the growing season. Seeds of ragweed were sown on July 8 th 2011 at a depth of $2 \mathrm{~cm}$ in each pot; the pots without the drainage holes were $15 \mathrm{~cm}$ tall and $19 \mathrm{~cm}$ wide. To ensure homogeneity of growing conditions, pots contained a mixture of peat $(70 \%)$, perlite $(10 \%)$, vermiculite $(10 \%)$ and sand $(10 \%)$. Pots were watered to field capacity once after sowing to stimulate germination, later on $100 \mathrm{~mL}$ and $200 \mathrm{~mL}$ of water were applied every 3-5 days for low and high water level, respectively. After sowing, $30 \%$ of the total $\mathrm{N}$ treatment was uniformly applied as aqueous $\mathrm{NH}_{4} \mathrm{NO}_{3}$, after which the remaining $\mathrm{N}$ was divided and applied in three equal rates before ragweed reached V4 stage (4-leaves; BBCH 12) (Hess et al. 1997). At this growth stage ragweed was thinned to achieve the desired density three plants per pot and the pot surface was covered with aluminium membrane and attached with the rubber band to prevent soil evaporation (CliftonBrown and Lewandowski, 2000).

To ensure that plant growth was not limited by elements other than $\mathrm{N}$, other macro- and micronutrients were added separately on a schedule similar to that of $\mathrm{N}$ application. At each application single pot received $100 \mathrm{~mL}$ of modified nitrogen-free Hoagland solution containing $0.2 \mathrm{mM} \mathrm{KH_{2 }} \mathrm{PO}_{4}$, $1 \mathrm{mM} \mathrm{KCl}, 1 \mathrm{mM} \mathrm{CaCl} 2.2 \mathrm{H}_{2} \mathrm{O}, 0.4 \mathrm{mM} \mathrm{MgSO}{ }_{4} .7 \mathrm{H}_{2} \mathrm{O}, 1$

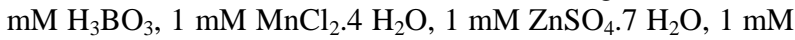
$\mathrm{CuSO}_{4} .5 \quad \mathrm{H}_{2} \mathrm{O}, 1 \mathrm{mM} \mathrm{H} \mathrm{MoO}_{4} \cdot \mathrm{H}_{2} \mathrm{O}$ and $1 \mathrm{mM}$ Fe-EDTA. Ragweed plants at each temporal block were harvested at following stages: V4, V10 and full flowering.

Half of the pots were used to determine the leaf relative water content (LRWC) of ragweed at each sampling according to Turner (1981). Between 10 and $14 \mathrm{~h}$, the youngest fully expanded leaves were selected and leaf tissue without major veins was excised, placed in pre-weighed vials and stored in a cooler. The vial weight with fresh ragweed leaves was recorded before hydration for $6 \mathrm{~h}$ at $10{ }^{\circ} \mathrm{C}$ in distilled water to ensure full turgidity. Fully turgid leaves were placed on filter paper to remove excess water and weighed. The samples were then oven-dried at $80{ }^{\circ} \mathrm{C}$ to constant mass and the weighed to determine the dry weight. The LRWC of the fresh leaves was calculated using the following equations (Kirkham, 2005):

LRWC $[\%]=[(\mathrm{FW}-\mathrm{DW}) /(\mathrm{TW}-\mathrm{DW})] \times 100$ where FW is the leaf fresh weight, TW is the leaf turgid weight and DW is the leaf dry weight (data not presented).

The plants in remaining pots were clipped at ground level, dry weights were determined after drying at $45{ }^{\circ} \mathrm{C}$ until a constant mass was achieved. Plant aboveground $\mathrm{N}$ content of each harvest was determined using modified Kjeldahl procedure.

Nitrogen use efficiency (NUE) was determined according to Berendse and Aerts (1987) using following equations:

$\mathrm{NUE}=\mathrm{NP} \times \operatorname{MRT}\left[\mathrm{g} \mathrm{DM} \mathrm{g}^{-1} \mathrm{~N}\right]$

$\left.\mathrm{NP}=\left(\mathrm{DW}_{2}-\mathrm{DW}_{1}\right) / \mathrm{N}_{\mathrm{A}}\right)\left[\mathrm{g} \mathrm{DM} \mathrm{g}^{-1} \mathrm{~N} \mathrm{day}^{-1}\right]$

where $\mathrm{DW}_{2}$ and $\mathrm{DW}_{1}$ are dry weights at the time $t_{2}$ (final sampling) and $\mathrm{t}_{1}$ (first sampling) and $\mathrm{N}_{\mathrm{A}}$ is the mean plant total nitrogen content averaged over three sampling intervals. MRT was determined as:

$\mathrm{MRT}=\mathrm{N}_{\mathrm{A}} \times \Delta \mathrm{T} / \mathrm{N}_{\mathrm{T}}$ (day),

where $\mathrm{N}_{\mathrm{T}}$ is the total $\mathrm{N}$ uptake in the period $\Delta \mathrm{T}$. Calculation of mean residence time (MRT) was based on the redefined concept from Hirose (2011), where MRT with respect to their $\mathrm{N}$ uptake and $\mathrm{N}$ losses can equally be applied to steady and non-steady state systems, therefore $\mathrm{N}$ losses were not estimated. NUE, NP and MRT represent mean values over the vegetative growth period.

Water-use efficiency (WUE) determination was based on the transpiration method (Clifton-Brown and Lewandowski, 2000), where the amount of dry matter produced, relative to the amount of water used during a growing period was determined using the following equation:

$\mathrm{WUE}=\mathrm{DW}_{\mathrm{R}} / \mathrm{DW}_{\mathrm{W}}$,

where $\mathrm{DW}_{\mathrm{R}}$ is the total dry weight of the ragweed plants and the $\mathrm{DW}_{\mathrm{W}}$ is the amount of water applied in the growing period. The total water was expressed as the sum of the applied water and the difference betweeen the initial and the final pot weight.

\section{Statistical analysis}

Statistical analysis was performed using the STATGRAPHICS Centurion XVI (2011, Statpoint Technologies, Warrenton, VA). To test assumptions of ANOVA data were tested for homogeneity and normality of variances with Levene's test and with ShapiroWilk's test. Two-way ANOVA was performed to test the significance of the main treatment effects, their replications and interactions. No interactions between nitrogen and water was observed for tested variables, thus the data were presented for each nitrogen and water levels. Means were compared with posthoc Tukey's HSD test at $\mathrm{P}<0.001$. 


\section{RESULTS}

As expected, ragweed final dry matter production was significantly influenced by nitrogen and water level $(\mathrm{P}<0.001)($ Table1).

Table 1.Significance levels in two-way ANOVA of the effects of nitrogen level (0 and $100 \mathrm{~kg} / \mathrm{ha})$ and water levels (low and high) on dry matter production, MRT (mean residence time, day), NP (nitrogen productivity, g DM $\mathrm{g}^{-1}$ day $^{-1}$ ), NUE (nitrogen use efficiency, $\mathrm{g} \mathrm{DM} \mathrm{g}^{-1} \mathrm{~N}$ ), WUE (water use efficiency, $\mathrm{g} \mathrm{DM} \mathrm{g}^{-1}$ water) of Ambrosia artemisiifolia L.

\begin{tabular}{lccccc}
\hline Terms & $\begin{array}{c}\text { Dry matter } \\
\text { production } \\
(\mathrm{g})\end{array}$ & $\begin{array}{c}\text { Mean } \\
\text { residence } \\
\text { time }(\mathrm{MRT})\end{array}$ & $\begin{array}{c}\text { Nitrogen } \\
\text { productivity } \\
(\mathrm{NP})\end{array}$ & $\begin{array}{c}\text { Nitrogen use } \\
\text { efficiency } \\
\text { (NUE) }\end{array}$ & $\begin{array}{c}\text { Water use } \\
\text { efficiency } \\
\text { (WUE) }\end{array}$ \\
\hline Nitrogen $(\mathrm{N})$ & $* * *$ & $\mathrm{~ns}$ & $\mathrm{~ns}$ & $* * *$ & $\mathrm{~ns}$ \\
Water $(\mathrm{W})$ & $* * *$ & $* * *$ & $* * *$ & $\mathrm{~ns}$ & $*$ \\
$\mathrm{~N} \times \mathrm{W}$ & $\mathrm{ns}$ & $\mathrm{ns}$ & $\mathrm{ns}$ & $\mathrm{ns}$ & $\mathrm{ns}$ \\
\hline
\end{tabular}

$* * * \mathrm{P}<0.001 ; * * \mathrm{P}<0.01 ; * \mathrm{P}<0.05 ; \mathrm{ns}=$ not significant.

Higher $\mathrm{N}$ level significantly increased ragweed dry matter production from $1.18 \mathrm{~g}$ to $1.86 \mathrm{~g}$ compared to low nitrogen treatment. Similarly higher water level increased ragweed dry matter production from $1.26 \mathrm{~g}$ to 1.87 g compared to low water level (Table 2, Fig 1a).
Mean residence time (MRT) was affected only by water level $(\mathrm{P}<0.001)$ and significantly different values of 5.75 to 9.24 day were observed for low and high water level, respectively (Table 2).

Table 2. Dry matter production, MRT (mean residence time, day), NP (nitrogen productivity, $\mathrm{g} \mathrm{DM} \mathrm{g}^{-1} \mathrm{day}^{-1}$ ), NUE (nitrogen use efficiency, $\mathrm{g} \mathrm{DM} \mathrm{g}^{-1} \mathrm{~N}$ ), WUE (water use efficiency, $\mathrm{g} \mathrm{DM} \mathrm{g}^{-1}$ water) at two levels of nitrogen-N (10 kg/ha-low and $100 \mathrm{~kg} / \mathrm{ha}$-high), and two water levels (low and high water level) of Ambrosia artemisiifolia L. Data presented are means with SE.

\begin{tabular}{lcccc}
\hline \multirow{2}{*}{ Parameter } & \multicolumn{2}{c}{ Nitrogen level } & \multicolumn{2}{c}{ Water level } \\
& Low & High & Low & High \\
\hline Dry matter & $1.18 \pm 0.14$ & $1.86 \pm 0.08$ & $1.26 \pm 0.15$ & $1.87 \pm 0.12$ \\
MRT & $58.33 \pm 8.53$ & $49.98 \pm 4.72$ & $67.83 \pm 6.88$ & $40.49 \pm 3.18$ \\
NP & $4.45 \pm 0.50$ & $5.07 \pm 0.51$ & $3.58 \pm 0.27$ & $5.95 \pm 0.38$ \\
NUE & $248.71 \pm 3.1$ & $222.10 \pm 3.2$ & $234.68 \pm 4.75$ & $236.11 \pm 6.1$ \\
WUE & $0.45 \pm 0.05$ & $0.52 \pm 0.05$ & $0.41 \pm 0.03$ & $0.57 \pm 0.05$ \\
\hline
\end{tabular}

Nitrogen productivity (NP) was influenced only by water $(\mathrm{P}<0.001)$, it significantly increased from 3.58 to $5.95 \mathrm{~g} \mathrm{DM} \mathrm{g}^{-1} \mathrm{~N}$ with higher water availability (Table 12, Fig 1b). Nitrogen use efficiency (NUE) was affected only by nitrogen level $(\mathrm{P}<0.001)$; it significantly decreased with nitrogen addition (Table 1-2, Fig 1c). Conversely, water use efficiency (WUE) significantly increased from $0.41 \mathrm{~g} \mathrm{DM} \mathrm{g}^{-1}$ to $0.57 \mathrm{~g} \mathrm{DM} \mathrm{g}^{-1}$ with higher water availability, compared to low water level (Table 1-2, Fig 1d). 

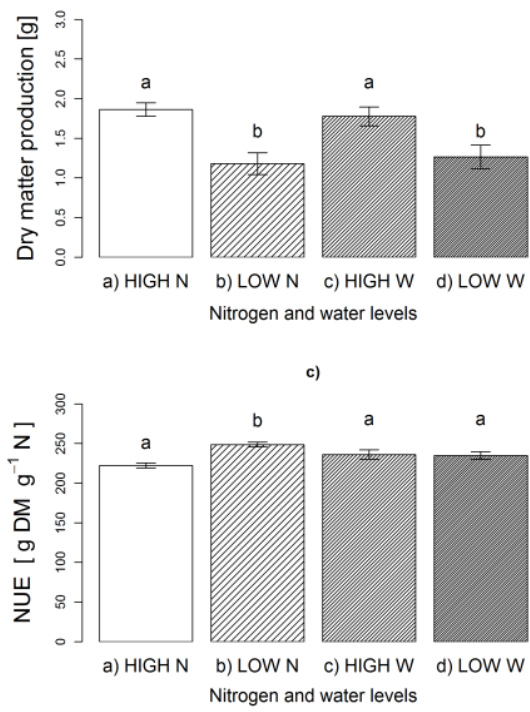

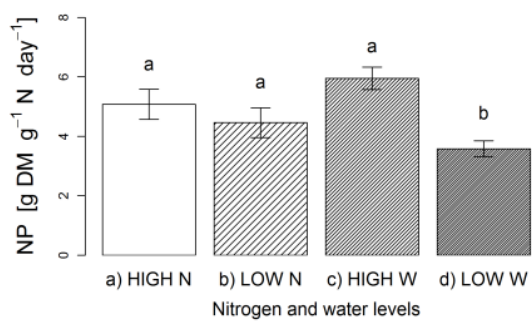

d)

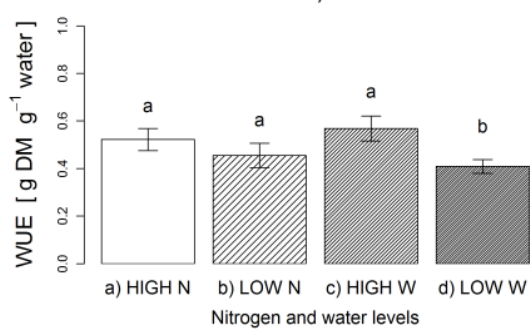

Figure 1. Dry matter production, MRT (mean residence time, day), NP (nitrogen productivity g $\mathrm{DM} \mathrm{g}^{-1}$ day $^{-1}$ ), NUE (nitrogen use efficiency, $\mathrm{g} \mathrm{DM} \mathrm{g}^{-1} \mathrm{~N}$ ), WUE (water use efficiency, $\mathrm{g} \mathrm{DM} \mathrm{g}^{-1}$ water) at two levels of nitrogen$\mathrm{N}$ (10 kg/ha-low N and $100 \mathrm{~kg} /$ ha-high $\mathrm{N}$ ), and two water levels (low W and high W) of Ambrosia artemisiifolia L. Data presented are means with SE. (Table1). Different letters present significant diferences for each nitrogen and water level at $\mathrm{P}<0.05$.

\section{DISCUSSION}

Results of our study confirmed report of ragweed's increased dry matter production with nitrogen addition (Lehoczky, 2008). Additionally, ragweed's dry matter production increase at higher water supply was rather expected. Beside dry matter production MRT, NP and NUE were also strongly affected by water availability. Our findings partially counter Yuan and Li (2007); they found that the species at higher water availability had higher MRT, whereas our results are displaying opposite pattern. At the same time, in both studies, similar NUE at various water supplies were observed. Moreover, in their study plants at low N supply had lower NP values than plants with high nitrogen supply, which is consistent with our results. MRT as a component of NUE was similar at both nitrogen levels, consistent with Aerts and De Caluwe (1989) report; they also found no differences in MRT at different $\mathrm{N}$ supplies. Higher MRT means also longer time of nitrogen presence in the plant and thus better use efficiency of the nitrogen absorbed by the plant.

The NUE of ragweed in our study was relatively high compared to results determined in previous reports, as NUE is both habitat and species dependent (Vázquez de Aldana and Berendse 1997; Nakamura et al., 2002). Our data are more similar to those obtained by Pajević et al. (2010) who report for NUE $224 \mathrm{~g} \mathrm{DM} \mathrm{g}^{-1} \mathrm{~N}$, when averaged across ragweed vegetative growth period.
Increased NUE in our study was not achieved through higher NP, but higher MRT was observed, due to higher $\mathrm{N}$ content in the plants (data not shown). A higher NP is associated with rapid growth, a relatively large investment of $\mathrm{N}$ in photosynthetic tissue, an efficient photosynthetic $\mathrm{N}$ use in leaves and relatively small proportion of carbon used for respiration (Garnier and Aronson, 1998; Lambers et al., 1998). Results of increased WUE at higher water supply was surprising, most authors have reported opposite pattern with reports of high WUE as a potential mechanism by which this invasive plant may increase the efficiency of resource capture (Pajević et al, 2010). We assume that our low water level was set to high, although our results of the ragweed leaf relative water content (LRWC) displayed substantial difference with values of $49.7 \%$ and $62.6 \%$ for low and high water level, respectively. Better explanation of these data would be possible if measurements of transpiration and photosynthesis would be done, and WUE could be determined from ratio photosynthesis/transpiration. Our results are in line with several authors reporting, that there is a trade-off between NUE and NP (Yuan and Li, 2007; Yuan et al, 2008). Similar NUE values were observed, with low NP and high MRT values or conversely with high NP and low MRT values. A high NUE is generally considered to be an adaption to a habitat with low soil nitrogen availability (Chapin, 1980). 
In conclusion, our results showed that ragweed exhibit different $\mathrm{N}$ use strategies at various $\mathrm{N}$ and water levels. High NUE, which was not contributed to high NP but rather by low nutrient loss rate with high MTR values, confirmed that ragweed displayed high adaptation to less fertile environments consistently with previous reports (Yuan et al., 2005). However, with increasing water supply ragweed altered its conservative strategy for low resource systems and increased NP and decreased MRT, although NUE remain similar. We observed fare more plastic response of the NUE underlying components in the response to water supply compared to nitrogen supply. The obtained data also supports hypothesis, that there is a trade-off between the NP and MRT. Our results suggest that water availability may play important role in the ragweed invasion success, as ragweed displayed high plasticity to water supply. Based on our observations, it can be presumed that ragweed will further spread into more productive habitats in combination with disturbance and other environmental stressors which decrease the competition intensity, but further focused studies on ragweed resource and adaptive traits are needed to explain its invasion und underlying plant traits.

\section{REFERENCES}

Aerts R., De Caluwe, H. 1989. Aboveground productivity and nutrient turnover of Molinia caerulea along an experimental gradient of nutrient availability. Oikos 54: 320-324

Berendse F., Aerts R. 1987. Nitrogen-use-efficiency: A biological meaningful definition? Functional Ecology 1: 293-296

Bonnot E.J. 1967. Ambrosia artemisiifolia L. Bulletin Mensuel de la Socie'te' Linne'enne de Lyon 36: 348-359

Chapin F.S. III. 1980. The mineral nutrition of wild plants. Annual Review of Ecology and Systematics 11, 233-260.

Chauvel B., Dessaint F., Cardinal-Legrand C., Bretagnolle F. 2006. The historical spread of Ambrosia artemisiifolia L. in France from herbarium records. Journal of Biogeography. 33: 665-673

Claridge K., Franklin S.B. 2002. Compensation and plasticity in an invasive plant species. Biological Invasions 4: 339347

Clifton-Brown J.C., Lewandowski I. 2000. Water use efficiency and biomass partitioning of three different Miscanthus Genotypes with limited and unlimited water supply. Annals of Botanny 86: 191-200

Daehler C.C. 2003. Performance comparisons of co-occurring native and alien invasive plants: implications for conservation and restoration. Annu Rev Ecol Syst 34: 183-211

Dahl A., Strandhed S.O., Wihl J.A. 1999. Ragweed - an allergy risk in Sweden. Aerobiologia 15: 293-297

DiTommaso A. 2004. Germination behaviour of common ragweed (Ambrosia artemisiifolia) populations across a range of salinities. Weed Science 52: 1002-1009

Durand L. Z., Goldstein G. 2001. Photosynthesis, photoinhibition, and nitrogen use efficiency in native and invasive tree ferns in Hawaii. Oecologia 126: 345-354

Dukes J.S., Mooney H.A. 1999. Does global change increase the success of biological invaders? Trends in Ecology and Evolution 14: 135-139

Feng Y.L., Auge H., Ebeling S.K. 2007. Invasive Buddleja davidii allocates more nitrogen to its photosynthetic machinery than five native woody species. Oecologia 153: $501-10$

Fumanal B., Gaudot I., Bretagnolle F. 2008a. Seed-bank dynamics in the invasive plant, Ambrosia artemisiifolia L. Seed Science Research 18: 101-114

Fumanal B., Girod C., Fried G., Bretagnolle F., Chauvel, B. 2008b. Can the large ecological amplitude of Ambrosia artemisiifolia explain its invasive success in France? Weed. Res., 48(4): 349-359

Funk J.L., Vitousek P.M. 2007 . Resource-use effi ciency and plant invasion in low-resource systems. Nature 446: 1079 $-1081$

Garnier E., Aronson J. 1998. Nitrogen-use efficiency from leaf to stand level: clarifying the concept. In: Lambers, H., Poorter, H., van Vuuren, M.M.U. (Eds.), Inherent Variation in Plant Growth. Physiological Mechanisms and Ecological Consequences. Backhuys, Leiden, The Netherlands, pp. 515-538

Gross K. L., Mittelbach G. G., Reynolds H. L. 2005. Grassland invasibility and diversity: responses to nutrients, seed input, and disturbance. Ecology 86: 476486

Hess M., Barralis G., Bleiholder H., Buhr L., Eggers T.H., Hack H., Stauss R. 1997. Use of the extended BBCHscale - general for the descriptions of the growth stages of monoand dicotyledonous weed species. Weed Research, 37: 433-441

Huenneke L. F., Hamburg S. P., Koide R., Mooney H. A. Vitousek P. M. 1990. Effects of soil resources on plant invasion and community structure in California serpentine grassland. Ecology 71: 478-491

Kirkham M.B.2005. Principles of soil and plant water relations. Elsevier, Burlington. pp 301

Lambers H, Chapin F.S. III, Pons T.L. 1998. Plant physiological ecology. Springer, New York

Lehoczky E. 2008. Growth of common ragweed (Ambrosia artemisiifolia L.) as a function of different nitrogen rates. In: Proceedings of the First International Ragweed Conference, Budapest, Hungary pp 51 
Water and nitrogen use efficiency of common ragweed (Ambrosia artemisiifolia L.) at different nitrogen and water levels

Mack R.N., Simberloff D., LonsdaleW.M., Evans H., Clout M., Bazzaz F. 2000. Biotic invasions: Causes, epidemiology, global consequences, and control. Ecological Applications 10: 689-710

Mitich L.W. 1996. Ragweeds (Ambrosia spp.) — the hay fever weeds. Weed Technology 10: 236-240

Nakamura T., Uemura S., Yabe K. 2002. Variation in nitrogen- use traits within and between five Carex species growing in the lowland mires of northern Japan. Functional Ecology 16: 67-72

Niinemets U., Valladares F., Ceulemans R. 2003. Leaf-level phenotypic variability and plasticity of invasive Rhododendron ponticum and non-invasive Ilex aquifolium cooccurring at two contrasting European sites. Plant Cell and Environment 26: 941-956

Pajević S., Borišev M., Orčić, Boža P., Nikolić N. 2010. Photosynthetic and Biochemical Characteristics of Invasive Species (Ambrosia artemisiifolia L., Ambrosia trifida L. and Iva xanthifolia Nutt.) Depending on Soil Humidity and Phenological Phase. Russian Journal of Ecology. 41(6): 498-505

Turner N.C. 1981. Techniques and experimental approaches for the measurement of plant water status. Plant and Soil 58: $339-366$
Vázquez de Aldana B.R., Berendse F. 1997. Nitrogen-use efficiency in six perennial grasses from contrasting habitats. Functional Ecology 11: 619-626

Vitousek P.M. 1982. Nutrient cycling and nitrogen use efficiency. American Naturalist 119: 553-572.

Vitousek P.M., Howarth R.W. 1991. Nitrogen limitation on land and in the sea: How can it occur? Biogeochemistry 13: $87-115$

Vogl G., Smolik M., Stadler L.M., Leitner M., Essl F., Dullinger S., Kleinbauer I., Peterseil J. 2008. Modelling the spread of ragweed: Effects of habitat, climate change and diffusion. European Physical Journal of Special Topics. 161: 167-173

Yuan Z., Li L., Huang J., Han X., Wan S. 2005. Effect of Nitrogen Supply on the Nitrogen Use Efficiency of an Annual Herb, Helianthus annuus L. Journal of Integrative Plant Biology 47: 539-548

Yuan Z.Y., Li L.H. 2007. Soil water status influences plant nitrogen use: a case study. Plant and Soil 301: 303-313

Yuan Z.Y., Chen H.Y.H., Li L.H. 2008. Nitrogen use efficiency: does a trade-off exist between the $\mathrm{N}$ productivity and the mean residence time within species? Australian Journal of Plant Botany 56: 272-277

Ziska L.H, 2001. My view. Weed Science 49: 437-438 